\title{
INFLUENCE OF PSYCHOSOCIAL AND ENVIRONMENTAL FACTORS ON TOBACCO USE AMONGST STUDENTS
}

\author{
${ }^{1}$ KHALOUD TARIQ, ${ }^{2}$ AHMED BILAL, ${ }^{3}$ UMAIR DASTGIR BHATTI
}

\begin{abstract}
Aim of this study was to find out the influence of psychosocial and environmental factor on tobacco use amongst students.

A cross sectional survey was conducted in 6 randomly selected Universities of Lahore from 1st to 28 September 2017. Seventy students were selected from each university through random sampling using lotery method using random number generator. Standardized global youth tobacco survey (GYTS) questionnaire was used. It was composed of pyschosocial \& environmental factors and was hand distributed among students. The data were analyzed using SPSS 20.
\end{abstract}

A total number of 420 students participated. Five incomplete responses were discorded. Females were 223 \& males were 192. Majoristy of the participants belonged to the age group of 18-24 years.

It was concluded that many students considered it a fun to do with friends.

Key Words: Psychosocial \& environmental factors influence, Tobacco use amongst students.

\section{INTRODUCTION}

In recent years, efforts have been made to reduce tobacco consumption however, the rate of tobacco usage has risen specially among young adults and in developing countries like Pakistan. ${ }^{1}$

According to national health survey of Pakistan, $55 \%$ males and $20 \%$ females have used tobacco in one form or another ${ }^{1}$ with frequency of use of smokeless tobacco being $7.7 \% .^{2}$ Amongst youth, the prevalence has been estimated to be $6.3 \%{ }^{3}$ The smoking prevalence amongst university students of Pakistan, has been estimated to be $15 \%{ }^{4}$

Various studies have shown that psychosocial and environmental factors remain most influential in instigation of tobacco use. ${ }^{5,6,7}$ Psychosocial factors include peer pressure, smoking approval of family member/ friend, and distress among many ${ }^{6,7}$ Different behavioral theories have tried to establish relation of habits like smoking and drinking with factors like psychosocial

${ }^{1}$ Dr Khaloud Tariq, BDS, BSc, MPH, Senior Demonstrator, Department of Community and Preventive Dentistry, The University of Lahore, Lahore Email: khaloud.tariq@ucd.uol.edu.pk

${ }^{2}$ Dr Ahmed Bilal (Corresponding), BDS, Demonstrator, Department and Community and Preventive Dentistry, The University of Lahore, Lahore, Address: 18-C, Lahore Press Club Society, Email: ahmed.bilal77@gmail.com

${ }^{3}$ Dr Umair Dastgir Bhatti, BDS, MSc, MFGDP, DDPHRCS, Associate

Professor, Department of Community and Preventive Dentistry, The University of Lahore, Lahore, Email: umairbhatti@doctor.com Received for Publication: Dec 27, 2017

First Revision: April 1, 2018

Second Revision: March 2, 2019

Approved: and environmental influences. ${ }^{8,9}$ Psychosocial factors are the direct cause for youngsters to be susceptible to adopting tobacco use. ${ }^{7,10}$ The most important reason for that is youngsters will acquaint themselves with such peers who have already established smoking habits, thus assuming the position of a role model for vulnerable youth. ${ }^{11}$ Also, perception of social acceptance by such peers may drive them to continue smoking habits. ${ }^{11}$ As far as environmental influences are concerned, advertisement of tobacco products, availability and ease to access are reasons for increase in use of those products. ${ }^{12}$ Moreover, if this is coupled with a member of family, such as a parent; consuming tobacco, it will perpetuate habit of using tobacco amongst young individual as such atmosphere represents a receptive environment. ${ }^{13} \mathrm{Also}$, since students spend a considerable amount of time in colleges and universities, a smoke-free environment is important in preventing tobacco use. Once regular tobacco use begins, cessation is difficult, which emphasizes on the importance of prevention of adolescent. Little work has been done to quantify the influence of psychosocial and environmental factors on tobacco use specially in Pakistan. The aim of this study was to assess the influence of psychosocial factors on use of tobacco products amongst students of various universities of Lahore, Pakistan.

\section{METHODOLOGY}

A cross sectional survey was conducted in 6 randomly selected universities of Lahore from $1^{\text {st }}$ to 28 September 2017. After obtaining approval from the 
Ethical Committee of University College of Dentistry, University of Lahore; permission was also obtained from the relevant universities to conduct the study. Seventy students were selected from each university through simple random sampling using lottery method using random number generator. Standardized global youth tobacco survey (GYTS) questionnaire was used in the study. The questionnaire was piloted amongst 100 students of the University of Lahore. This was followed by feedback from same students regarding ease of understanding the questionnaire. It was found that the questionnaire was easy to understand and could be independently completed by participants without difficulty. The structured questionnaire was composed of demographic questions such as age, and gender along with psychosocial factors regarding offer by family members and friends and their perception towards tobacco use. It also included questions associated with effect of environmental factors. The responses "yes", "maybe yes", and "maybe no" were grouped together for coding and analysis as they implied propensity towards "yes". An informed consent document was also attached to the questionnaire which contained information about the aims of the study and how the data will be used for analysis and dissemination of results. All students aged 17-30 could participate in the study. No identifiable data like name, email address was obtained from the participants to maintain their confidentiality. Sample size calculated with $95 \%$ confidence interval and approximately 5\% margin of error was 323 .

The questionnaire was hand distributed among the

TABLE 1.1- PERCEPTION OF TOBACCO USE AMONGST RESPONDENTS

\begin{tabular}{lll|}
\hline $\begin{array}{l}\text { Use of chewable to- } \\
\text { bacco in adult life }\end{array}$ & 145 (34.9\%) & $\mathbf{2 7 0}$ (57.8\%) \\
\hline $\begin{array}{l}\text { Use of cigarettes in } \\
\text { adult life }\end{array}$ & $159(38.3 \%)$ & $256(61.6 \%)$ \\
$\begin{array}{l}\text { Use of tobacco is grown } \\
\text { up and brave }\end{array}$ & $132(31.8 \%)$ & $283(68.1 \%)$ \\
$\begin{array}{l}\text { Use of tobacco fashion- } \\
\text { able }\end{array}$ & $175(42.1 \%)$ & $240(57.8 \%)$ \\
$\begin{array}{l}\text { Use of tobacco fun with } \\
\text { friends }\end{array}$ & $202(48.6 \%)$ & $213(51.3 \%)$ \\
$\begin{array}{l}\text { Use of tobacco is attrac- } \\
\text { tive to boys }\end{array}$ & $202(48.6 \%)$ & $213(51.3 \%)$ \\
$\begin{array}{l}\text { Use of tobacco is attrac- } \\
\text { tive to girls }\end{array}$ & $158(38 \%)$ & $257(61.9 \%)$ \\
$\begin{array}{l}\text { Will try chewable tobac- } \\
\text { co if offered by family/ } \\
\text { friend }\end{array}$ & $168(40.4 \%)$ & $247(59.5 \%)$ \\
$\begin{array}{l}\text { Will try cigarette if } \\
\text { offered by family/friend }\end{array}$ & $164(39.5 \%)$ & $251(60.4 \%)$ \\
\hline
\end{tabular}

TABLE 1.2-PERCEPTION OF APPROVAL OF PEERS ON USE OF TOBACCO BY RESPONDENT

\begin{tabular}{|lcc|}
\hline Variable & Yes N (\%) & No N (\%) \\
\hline $\begin{array}{l}\text { Parents will approve of } \\
\text { tobacco use }\end{array}$ & $45(10.8 \%)$ & $370(89.1 \%)$ \\
$\begin{array}{l}\text { Teachers will approve } \\
\text { of tobacco use }\end{array}$ & $75(18 \%)$ & $340(81.9 \%)$ \\
$\begin{array}{l}\text { Relatives will approve } \\
\text { of tobacco use }\end{array}$ & $104(25 \%)$ & $311(74.9 \%)$ \\
$\begin{array}{l}\text { Close friends will ap- } \\
\text { prove of tobacco use } \\
\text { Boys in university will } \\
\text { approve of tobacco use } \\
\text { Girls in university will } \\
\text { approve of tobacco use }\end{array}$ & $163(38.5 \%)$ & $255(61.4 \%)$ \\
\hline
\end{tabular}

TABLE 2.1- RESPONSES OF PARTICIPANTS TO ENVIRONMENTAL FACTORS

\begin{tabular}{|lc|}
\hline Variable & N (\%) \\
\hline Last discussed lesson in university about tobacco \\
1-6 months & $197(47.4 \%)$ \\
$7-12$ months & $67(16.1 \%)$ \\
More than a year & $57(13.7 \%)$ \\
Never & $94(22.6 \%)$ \\
Shops refused to sell tobacco to young students in \\
past 30 days \\
Yes & $49(11.8 \%)$ \\
No & $177(42.7 \%)$ \\
Didn't try to purchase & $189(45.5 \%)$ \\
obacco & \\
Presence of law prohibiting smoking in public places \\
Yes, implemented & $33(7.9 \%)$ \\
Yes, but notimplemented & $161(38.7 \%)$ \\
No & $221(53.2 \%)$ \\
Presence of law prohibiting selling tobacco under \\
18 years \\
Yes, implemented & $21(5 \%)$ \\
Yes, butnotimplemented & $176(42.4 \%)$ \\
No & $218(52.5 \%)$ \\
\hline
\end{tabular}

students by 4 survey managers who visited the universities on various dates. The data was analyzed using Statistical Package for Social Sciences (SPSS) version 22. Descriptive statistics were reported as frequency $(\%)$.

\section{RESULTS}

A total number of 420 students participated in the 
study however, 5 incomplete responses were discarded, making the final figure 415 . The number of female participants in the study was 223 and male participants were 192. Majority (92\%) of the participants belonged to the age group of 18-24 with $2.2 \%$ being less than 18 years and $5.8 \%$ more than 24 years.

The responses of few questions regarding influence of psychosocial factors on use of tobacco are summarized in table 1.1. Responses related to approval of peers on use of tobacco by respondents are charted in table 1.2 Table 2.1 shows the response of questions that were related to environmental factors which influences the use of tobacco in university.

\section{DISCUSSION}

Many of the respondents in the study expressed their intention of not using tobacco in any form in the near future. This could depict that the respondents were knowledgeable about the negative effects of tobacco use; which corresponds with a study where students demonstrated awareness of the hazards of tobacco. ${ }^{13}$ Psychosocial factors, to some extent, involve influence of peers. Earlier studies have exhibited the importance of peer and parental smoking as risk factors..$^{14,15,16} \mathrm{~A}$ study conducted in India indicated that smoker friends influenced tobacco usage, that is, they were more likely to instigate tobacco use. ${ }^{17}$ This study also attempted to evaluate if respondents would use tobacco when offered by a friend or a family member. Although, most respondents seemed to reject such an offer, if it were made, many responded that they would try it.

Young people are generally influenced by their social circle and tend to lean towards risky behaviour and activities considered "fashionable" or "cool" amongst peers. However, a recent research conducted in Australia demonstrated that the current trend contrasts previous observations..$^{18}$ Individuals who smoked often were labelled as 'losers' or 'trying too hard to be cool' and rejection of an offer of cigarettes was considered socially acceptable among many young cohorts..$^{18}$ Correspondingly, in this study though most respondents did not consider tobacco use a gratifying activity, some deliberated that it was a fun activity.

Parents and peer's approval has been deemed as important determinants of susceptibility to start smoking. Overwhelming majority of participants in this study responded that uptake of smoking by them will not be appreciated by parents and peer. Similar results were obtained in another study where $98 \%$ of respondents were sure that their parents and friends would not respond negatively. ${ }^{15}$

It was insinuated by respondents that much information regarding tobacco wasn't communicated to them by the university. Also, majority of them were unaware of laws and policies regarding tobacco use. For example, since 2002; a Health Ordinance Act was passed that included laws regarding prohibition of smoking and protection of non-smokers. ${ }^{19}$ The laws included were related to the smoking in public areas and selling of cigarettes among others. The fact that most of the students were unable to recall existence of such laws represent ineffective execution, and advertisement of existing regulations on the part of the provincial and federal government.

\section{CONCLUSION}

The study indicates that most students are unlikely to use tobacco in future however, many consider it a fun activity to do with friends. Also, majority of participants were unaware of existence of tobacco prohibition laws. Many also thought that other boys would like it if they smoked which shows that in absence of stricter policies, they might use tobacco under influence of peers.

\section{Recommendation}

Prevention of tobacco related issues can only be accomplished by implementing measures that incorporate interventions to modify behaviors along with the objective of decreasing demand. ${ }^{20}$ Findings of this study suggest reemphasizing on the need to integrate effective tobacco control measures not only in the educational institutions but also in areas at close vicinity.

\section{REFERENCES}

1 Pakistan Medical Research Council. National Health Survey of Pakistan 1990-94. Network Publication Service, 1998. [Last Accessed: 15 December 2017]

2 The Tobacco Atlas. Fact Sheet. 2018. Retrieved from https:// tobaccoatlas.org/country/pakistan [Last Accessed: 20 June 2018]

3 Aslam SK, Zaheer S, Rao S, Shafique K. Prevalence and determinants of susceptibility to cigarette smoking among school students in Pakistan: secondary analysis of Global Youth Tobacco Survey. Subst Abuse Treat Prev Policy 2014; 9(10).

4 Afzal M, Majeed A, Azad AH, Rizvi F, Tariq N. Frequency of cigarette and sheesha smoking among students of a private medical college. J Post Med Inst 2014; 28(4):378-82

5 Ra JS, Cho TH. Psychosocial factors associated with smoking intention in Korean male middle school students. The Journal of School Nursing 2016; 33(5):355-363.

6 Tyas SL, Pederson LL. Psychosocial factors related to adolescent smoking: a critical review of the literature. Tobacco Control 1998; 7:409-20.

7 Hayatbakhsh R, Mamun AA, Williams GM, O'Callaghan MJ, Najman JM. Early childhood predictors of early onset of smoking: A birth prospective study. Addictive Behaviors 2013; 38(10):2513-19.

8 Bandura A. Social foundations of thought and action: A social cognitive theory. Prentice-Hall. Englewood Cliffs; 1986.

9 Jessor R, Jessor S. Problem behavior and psychological development. Academic Press, New York; 1977.

10 Salvy SJ, Pedersen ER, Miles JNV, Tucker JS, D’Amico EJ. Proximal and distal social influence on alcohol consumption 
and marijuana use among middle school adolescents. Drug and Alcohol Dependence 2014; 144(1):93-101.

11 Tran BX, Nguyen LH, Vu GT et al. Online peer influences are associated with receptiveness of youth: The case of Shisha in Vietnam. Children and Youth Services Review 2019; 99:18-22

12 Kim AE, Nonnemaker JM, Loomis BR et al. Influence of Tobacco Displays and Ads on Youth: A Virtual Store Experiment. Pediatrics 2013; 131(1):88-95

13 Al-Haqwi AI, Tamim H, Asery A. Knowledge, attitude and practice of tobacco smoking by medical students in Riyadh, Saudi Arabia. Annals of Thoracic Medicine 2010;5(3):145-148.

14 Cresswell WH, Huffman WJ, Stone DB. Youth smoking: behavior characteristics and their educational implications. A report of the University of Illinois Anti-Smoking Education Study 1970.

15 Scalici F, Schulz PJ. Parents' and peers' normative influence on adolescents' smoking: results from a Swiss-Italian sample of middle schools students. Subst Abuse Treat Prev Policy 2017;12(1):5.

16 Mays D, Gilman SE, Rende R, Luta G, Tercyak KP, Niaura RS. Parental Smoking Exposure and Adolescent Smoking Trajectories. Pediatrics 2014;133(6):983-91.
17 Nichter M, Nichter M, Sickle VD. Popular perceptions of tobacco products and patterns of use among male college students in India. Soc Sci Med 2004;59(2):425-31

18 Wood L, Lang A and Coase P. Smarter than Smoking Qualitative Research. A research report. West Perth, Australia: TNS Social Research, 2005.

19 Society for Alternative Media and Research, Coalition for Tobacco Control-Pakistan. Stubbing it Out: Status of Enforcement of Tobacco Control Laws in Pakistan. 2017. Retrieved from http://www.ctcpak.org/archive/CTCPAK_TIA\%20Report\%20 Stubbing\%20It\%20Out\%20April\%2017\%27.pdf[LastAccessed: 28 December 2017]

20 Najabat A, Abbas J, Muhammad A, Murtazain R, Najaf A. The Economic Analysis of Tobacco Industry: A Case Study of Tobacco Production in Pakistan. International Journal of Research 2015; $2(3)$.

\section{Khaloud Tariq: \\ 2 Ahmed Bilal: \\ 3 Umair Dastagir Bhatti:}

\section{CONTRIBUTIONS BY AUTHORS}

Write up and data analysis.

Data collection and write up.

Conception and reviewed the manuscript. 